\title{
BEAVERS (CASTORIDAE, RODENTIA) FROM THE LATE MIOCENE (MN 9) LOCALITY GRYTSIV IN UKRAINE
}

\author{
LEONID REKOVETS ${ }^{1,2, *}$, CLARA STEFEN ${ }^{3,},{ }^{*}$, VITALII DEMESHKANT ${ }^{2}$ \\ ${ }^{1}$ National Museum of Natural History NAS of Ukraine, 15 Bohdan Khmelnytskyi St., 01030 Kyiv, Ukraine; \\ e-mail: leonid.rekovets@upwr.edu.pl. \\ ${ }^{2}$ Wroclaw University of Environmental and Life Sciences, 25 Norwida St., 50-375 Wrocław, Poland; e-mail: vitalii.demeshkant@upwr.edu.pl. \\ ${ }^{3}$ Senckenberg Naturhistorische Sammlungen Dresden, 159 Königsbrücker Landstraße, 01109 Dresden, Germany; \\ e-mail: clara.stefen@senckenberg.de. \\ * corresponding author
}

Rekovets, L., Stefen, C., Demeshkant, V. (2020): Beavers (Castoridae, Rodentia) from the late Miocene (MN 9) locality Grytsiv in Ukraine. - Fossil Imprint, 76(1): 165-173, Praha. ISSN 2533-4050 (print), ISSN 2533-4069 (on-line).

\begin{abstract}
Here we report about the presence of fossils belonging to different beaver lineages from the late Miocene (MN 9, Vallesian) of Grytsiv (western Ukraine). Among them, nine isolated molars were assigned to Chalicomys jaegeri and described in detail here for the first time. Morphologically and metrically these specimens fit well into the range known for this species from other localities. The teeth are of different wear stages, mainly moderately or strongly worn. Two other teeth (a germ and one with a little wear), are tentatively identified as belonging to a smaller-sized beaver resembling Euroxenomys minutus. This is based mainly on their smaller size as measured at the occlusal surface. Taxonomic status and palaeoecology of Chalicomys jaegeri and other species of this genus are discussed in the paper.
\end{abstract}

Key words: Chalicomys jaegeri, Euroxenomys minutus, teeth, morphology, Eastern Europe

Received: June 13, 2019 | Accepted: April 14, 2020 | Issued: November 9, 2020

\section{Introduction}

Beavers (family Castoridae) are known in the fossil record of Europe up from the early Miocene (Hugueney 1999, Stefen 2011). The taxonomic, morphological, and geological history of these rodents has been presented in a number of publications dating from the nineteenth century. However, some of the evolutionary and taxonomic issues of this group of rodents are still debatable (Aldana Carrasco 1992, Korth 2002, Rybczynski 2007, Rekovets et al. 2009, Stefen 2020). A thorough analysis of publications regarding the history of the genus Chalicomys and morphologically related groups in Europe was presented by CasanovasVilar et al. (2008), Casanovas-Vilar and Alba (2011). There are also known data on the evolution of beavers on the basis of DNA studies with the reconstruction of their possible phylogenetic relationships (Horn et al. 2011, 2014). For Eastern Europe, including Ukraine, the study of extinct castorids is still inadequate, although their remains are frequently found in Miocene and Pliocene deposits (Topachevsky et al. 1987, Nesin and Nadachowski 2001, Rekovets et al. 2009). The scarce information available on the ultrastructure of the tooth enamel of extinct beavers and other rodents from this region was published several years ago (Rekovets and Nowakowski 2013, Rekovets and Kovalchuk 2017, Nowakowski et al. 2018).

However, it is necessary to conduct a thorough morphological and taxonomic revision of the osteological material previously assigned to the family Castoridae, followed by a study of the systematics and evolution of beavers in this part of Europe (see Maul et al. 2013, Apoltsev and Neofitny 2014, Apoltsev and Rekovets 2015 about the study of the fossil remains of Trogontherium and Chalicomys).

The main task of our research is to analyse the dental morphology and taxonomic status of beavers from the late Miocene locality Grytsiv in western Ukraine (Text-fig. 1). This locality was discovered in 1982 by a local historian V. N. Kushniruk. Korotkevich (1988) and Topachevsky et al. (1996) characterised the rich fauna of Grytsiv as one of the most ancient in Eastern Europe (MN 9, with species of the Anchitherium fauna). The mammalian fauna of this age was assigned to the Gritsevian faunal complex (Nesin and Nadachowski 2001), which corresponds to Vallesian (MN 9-10). The fauna of this locality resembles that of Can Llobateres in Spain and Klimentovichi in Ukraine (Korotkevich 1988, Topachevsky et al. 1997). 


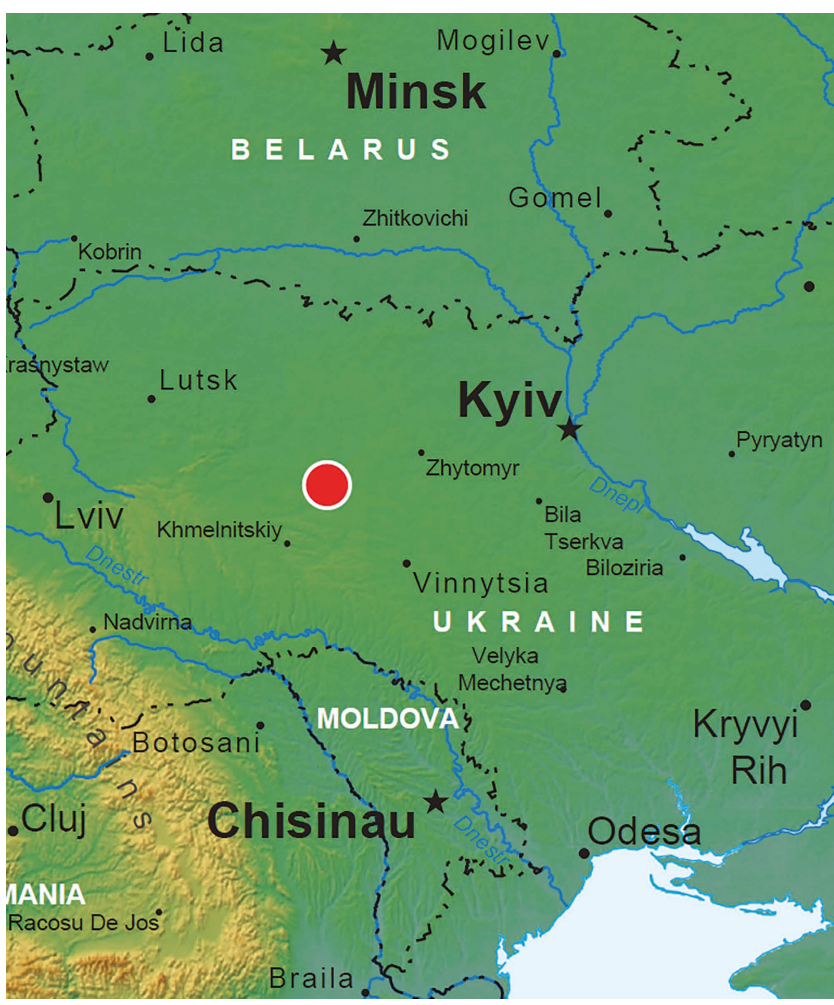

Text-fig. 1. Location of Grytsiv locality, Ukraine.

According to Nesin (2013), the species list of mammals from Grytsiv comprises 31 taxa representing the orders Eulipotyphla, Lagomorpha, and Rodentia. Large mammals include Gomphotherium sp., Chalicotherium sp., Hipparion primigenium, Euprox sp., and Lagomeryx sp. as well as representatives of Carnivora. Numerous remains of other vertebrates (reptiles, amphibians, and fishes) were also found there (Korotkevich 1988, Topachevsky et al. 1996, Nesin 2013, Kovalchuk 2017).

The fossil remains of beavers from Grytsiv were reported under various names - Monosaulax sp., Chalicomys castoroides, Steneofiber sp. (Nesin and Nadachowski 2001, Rekovets et al. 2009, Nesin 2013). However, the referred material was hardly investigated morphologically. Therefore, all available castorid fossils from this locality are reconsidered by ourselves and described in detail below.

\section{Material and methods}

For this study, 11 isolated teeth collected in 1990 were involved. These specimens are housed in the Department of Paleontology of the National Museum of Natural History (NMNHU-P), National Academy of Sciences of Ukraine (Kyiv), collection no. 22. Nine of these specimens were previously assigned to Chalicomys castoroides, while two others - to a smaller beaver species, Trogontherium minutum or Euroxenomys minutus (Hugueney and Duranthon 2012 argued for Euroxenomys minutum, but it is not within the scope of this study to go into detail here). The teeth were measured at the occlusal surface: length - largest extension in mesio-distal direction, width - largest extension in linguobuccal direction. The length to width ratio of the occlusal surface is given as a percentage. These measurements are used commonly but not necessarily at the straight angle to the long tooth axis. The height of the teeth was measured as maximum height $\left(\mathrm{H}_{\max }\right)$ from the end of the root to the top of the protoconid or hypocone, while the minimum height $\left(\mathrm{H}_{\min }\right)$ - from the end of the root to the hypoconid or protocone (not necessarily at the straight angle to the chewing surface). The dental terminology follows Stirton (1935) and Hugueney (1999), which in turn partly adapted them from Wood and Wilson (1936). We used uppercase letters for upper teeth and lowercase letters for lower teeth.

\section{Systematic palaeontology \\ Family Castoridae HeMPRICH, 1820 \\ Genus Chalicomys KAUP, 1832}

Comments. The anatomy and dental morphology of Chalicomys (Kaup 1832) is similar to that of the genus Castor. Therefore, during the morphometric analysis, it is important to distinguish morphological features that are specific only for Chalicomys. Those diagnostic features, according to Casanovas-Vilar et al. (2008), are less hypsodont teeth with developed roots, less extensive cement, shorter hypostria and hypostriids, longer both upper and lower third molars in relation to other molars (however, the M3 is not extended as in Trogontherium). In addition, there is a long and "8"-shaped p4 like those in Steneofiber but differs from the latter in greater size, stronger hypsodonty, and the development of tetralophodont pattern.

\section{Chalicomys jaegeri KAUP, 1832}

$$
\text { Pl. 1, Figs 1-9 }
$$

1832 Palaeomys castoroides; Kaup, p. 993, pl. XXVI, figs 1-4.

1832 Chalicomys Jaegeri; Kaup, p. 995, pl. XXVI, figs 1-6.

1832 Chelodus typus; Kaup, p. 996, pl. XXVI, figs 1, 2.

1948 Castor vidali n. sp.; Crusafont Pairó et al., p. 348, fig. 4, pl. II, figs $1-4$.

2009 Palaeomys castoroides Kaup, 1832; Rekovets et al., p. 99.

2001 Steneofiber sp.; Nesin and Nadachowski, p. 112, tab. 1.

2013 Monosaulax sp.; Nesin, p. 17.

2013 Palaeomys sp.; Nesin, p. 17.

2013 Palaeomys castoroides; Rekovets and Nowakowski, p. 160, fig. IA, IB.

Material. Two p4 (NMNHU-P 22/214, 22/215), four P4 (NMNHU-P 22/211, 22/212, 22/213, 22/216), two M1/2 (NMNHU-P 22/219, 22/220), one M3 (NMNHU-P 22/222).

De s c ription. The right p4 (NMNHU-P 22/214; Pl. 1, Fig. 1a-c) is slightly worn and belongs to a fairly young individual. On the occlusal surface, the paraflexid is slightly longer than the metaflexid, oriented diagonally, and opens mesially and lingually. The mesial opening is represented by a single tiny striid. All flexids are orientated diagonally on the occlusal surface. Para- and metaflexids extend nearly from side to side of the tooth width. The mesostriid ends adjacent and slightly mesial to the short hypoflexid. On the lingual side, striids are well visible: the parastriid is the shortest $(2.5 \mathrm{~mm})$, the metastriid is $3.5 \mathrm{~mm}$ long, and the mesostriid is the longest $(8.5 \mathrm{~mm})$ and extends to almost half of the crown height (Pl. 1, Fig. 1c). On the buccal 
Table 1. Measurements of the studied beaver teeth from Grytsiv. The collection numbers of the material in the Paleontological Museum of the National Museum of Natural History (Kyiv, Ukraine).

\begin{tabular}{|c|c|c|c|c|c|}
\hline Collection number & $\begin{array}{c}\text { Tooth } \\
\text { position }\end{array}$ & Length & Width & $\begin{array}{c}\text { Height } \\
\text { min }\end{array}$ & $\begin{array}{c}\text { Height } \\
\text { max }\end{array}$ \\
\hline \multicolumn{6}{|c|}{ Chalicomys jaegeri } \\
\hline Grytsiv - № 22-214 & $\mathrm{p} 4$ & 9.7 & 8 & 21.3 & 24.1 \\
\hline Grytsiv - № 22-215 & $\mathrm{p} 4$ & 10 & 7.2 & 21.8 & 24.2 \\
\hline Grytsiv - № 22-211 & $\mathrm{P} 4$ & 10.02 & 8.6 & 16.2 & 19.2 \\
\hline Grytsiv - № 22-212 & $\mathrm{P} 4$ & 10 & 11 & 19.1 & 20 \\
\hline Grytsiv - № 22-213 & $\mathrm{P} 4$ & 7.5 & 6.7 & 22.9 & 23 \\
\hline Grytsiv - № 22-216 & $\mathrm{P} 4$ & 7.7 & 7.9 & 22.3 & 22.3 \\
\hline Grytsiv - № 22-219 & $\mathrm{M} 1 / 2$ & 7.3 & 7.9 & 14.6 & 16.7 \\
\hline Grytsiv - № 22-220 & $\mathrm{M} 1 / 2$ & 7.3 & 7.8 & 13.2 & 14 \\
\hline Grytsiv - № 22-222 & M3 & 7.9 & 6.2 & 13.4 & 15.4 \\
\hline \multicolumn{6}{|c|}{ cf. Euroxenomys minutus } \\
\hline Grytsiv - № 22-217 & M3 & 4.3 & 4.2 & 11.4 & 13.6 \\
\hline Grytsiv - № 22-218 & $\mathrm{P} 4$ & 6.2 & 5.1 & 15.9 & 15.9 \\
\hline
\end{tabular}

side, the hypostriid extends to the crown base (Pl. 1, Fig. 1b). There is a thin cement layer in this tooth with a little wear, as the genus Chalicomys is characterized by the appearance of cement in the ontogenesis process (Lychev 1977). The enamel thickness is almost the same around the entire tooth crown but slightly stronger at the hypo- and the entoconid, and thinner at the protoconid. The enamel surrounding the paraflexid shows some small crenulations. The measurements are presented in Table 1.

Another right p4 specimen (NMNHU-P 22/215; P1. 1, Fig. $2 \mathrm{a}-\mathrm{c}$ ) is slightly damaged at the mesial side, and the enamel is missing at the protoconid or anterolophid. The tooth is worn and belongs to a relatively young individual. Its paired root is poorly developed. Contrary to all the other examined fourth lower premolars, the parafossettid is closed.

The parafossettid is hook-like on the lingual side and curves towards the hypoflexid. The hypo- and the mesoflexid end adjacent and opposite to each other in about the middle of the tooth length. The mesoflexid is straight linguo-buccally and not curved mesially as in the other $\mathrm{p} 4$. The metaflexid starts straight at the lingual side but then curves mesially and extends diagonally on the occlusal surface towards the hypoflexid. The enamel surrounding the para- and the metaflexid show some crenulations. On the lingual side, there are a short metastriid $(0.8 \mathrm{~mm}$ long) and a longer mesostriid extending about half of the crown height. At the base of the mesostriid, there is an additional stylid (Pl. 1, Fig. 2c). There is cement in the meso- and hypostriid. The hypostriid on the buccal side extends to the crown base (Pl. 1, Fig. 2b). The enamel around the tooth is thin, particularly at the entoconid and the hypoconulid.

The right P4 (NMNHU-P 22/212; Pl. 1, Fig. 5a, b) is strongly worn so the para-, meta-, and mesoflexus are closed. The parafossette is curved or hook-like and is partially parallel to the hypoflexus on the occlusal surface. The hypoflexus extends over more than half of the tooth width; it is diagonally oriented and straight. The mesofossette is strongly curved (convex) and the smaller metafossette fills the distal part of the tooth. It is also slightly curved or hook-like and slightly diagonal linguo-distally. The enamel at the buccal, distal, and linguo-distal sides of the tooth is broken and thin. There are two well-developed roots. The hypostria ends above the crown base; it is very narrow, and filled with some cement.

Another right P4 specimen (NMNHU-P 22/213; P1. 1, Fig. 6a, b) is broken mesially and bucco-lingually. On the occlusal surface, the hypoflexus, mesoflexus and metaflexus are visible. On the lingual side, the hypostria does not reach the crown base. There are short meso- and metastriae on the lingual side.

The left P4 (NMNHU-P 22/211; Pl. 1, Fig. 7a, b) is associated with a small bone fragment, and shows open para-, hypo-, and mesoflexi and only a closed metafossette. The paraflexus extends slightly less than half of the tooth width and ends adjacent and opposite to the hypoflexus ("face to face"). Where they meet, both flexi show a small extension in mesial direction. The mesoflexus is narrow, strongly curved distally, and extends over the total tooth width nearly to the linguo-distal enamel. The smaller metafossette is nearly straight and occupies the distal part of the tooth.

Another specimen of left P4 (NMNHU-P 22/216; Pl. 1, Fig. 8a, b) shows closed para- and metafossette but open meso- and hypoflexid. The parafossette extends from the buccal side to the hypoflexus less than half of the occlusal surface. It ends mesially to the hypoflexus with an additional enamel fold. The mesoflexus is narrow and curves from the buccal opening to the linguo-distal side of the tooth. The metafossette is small but reaches diagonally from side to side on the occlusal surface. The enamel is thin, but thicker at the proto- and hypocone as well as the mesoflexus. The hypostria does not extend to the crown base.

The left $\mathrm{M} 1 / 2$ is represented by two specimens (NMNHU-P 22/219; Pl. 1, Fig. 4; NMNHU-P 22/220; Pl. 1, Fig. 3). Only the hypoflexus is open, and the hypostria does not extend to the crown base and has some cement. The paraflexus is directly adjacent (or "face to face") to the hypoflexid which extends over slightly more than half of the occlusal surface. The meso- and metafossette are slightly curved. The enamel on the lingual and distal sides is thin and partially worn. In contrast, it is thick on the mesial side of the tooth. Due to their advanced wear stage, the teeth are relatively low-crowned.

The left M3 (NMNHU-P 22/222; Pl. 1, Fig. 9) is strongly worn and all fossettes still present, here interpreted as hypo-, meso- and metafossette, are closed, and orientated linguobuccally. They appear "on the top of the previous one" on the occlusal surface. The mesofossette is strongly curved, the metafossette is small and oval, and the hypofossette is convex and the longest one. There are three roots.

\section{Genus Euroxenomys Samson et Rădulesco, 1973}

\section{cf. Euroxenomys minutus (von MeYer, 1838)} P1. 1, Figs 10-11

2015 Trogontherium (Euroxenomys) minutum minutum; Apoltsev and Rekovets, p. 521, fig. 1.

Comments. Two teeth from Grytsiv belong to a small-sized beaver, and these specimens are tentatively 
assigned resembling those to Euroxenomys minutus following Hugueney and Duranthon (2012). These authors accepted the genus as valid and not as a subgenus within Trogontherium.

D e s c ri p tion. The right P4 (NMNHU-P 22/218; Pl. 1, Fig. 11a, b) is broken at the base. The tooth is small and also appears more fragile than other beaver teeth from Grytsiv. The described specimen is slightly worn, its paraflexus has a tiny lateral opening. The metafossette is wide, appears to be just closed, and fills the distal part of the tooth. The mesoflexus has a wide buccal opening which shows some cement and is curved on the occlusal surface extending to the linguo-buccal side. The hypoflexus is straight, short, oriented diagonally, and ends in about the middle of the tooth width adjacent to the paraflexus. The hypostria extends lingually to the broken end of the tooth crown (Pl. 1, Fig. 11b). The specimen fits well into the size range of upper premolars of small beavers from Sansan assigned to Euroxenomys minutus (see Hugueney and Duranthon 2012 for details).

The left M3 (NMNHU-P 22/217; P1. 1, Fig. 10a, b) is not fully developed tooth germ. The tooth is small and slenderer than the other teeth assigned to Chalicomys. The tooth is unworn, without roots. The lingual hypostria is narrow and nearly reaches the crown base. The buccal mesostriia does not extend to the middle of the crown height. The ridges are visible on the occlusal surface. Anteriorly, at the protocone, there is a relatively wide fossette, interpreted herein as pre-parafossette. The narrow paraflexus shows a narrow lateral opening and extends to the hypoflexus on the occlusal surface. The hypoflexus appears as a pointed and wide triangle on the occlusal surface. Distal to the para- and hypoflexus, there is a narrow mesoflexid extending from side to side of the tooth. The metaflexus is open distally.

\section{Discussion}

Taxonomy of the castorid genus Chalicomys has been thoroughly revised by Casanovas-Vilar and Alba (2011). These authors follow Mörs and Stefen (2010) in suggesting that the fossils assigned to Chalicomys from the early middle Miocene (MN 4 to MN 6) should be referred as Steneofiber, and follow Stefen (2009) in questioning the validity of the assignment of later middle Miocene (namely MN 7 and MN 8) beaver material to Chalicomys. Thus, Chalicomys can be considered as occurring from the late Miocene (MN 9) to the Pliocene (Hugueney 1999). Thus, the description of the teeth of Chalicomys jaegeri from Grytsiv interpreted to be MN 9 extends our knowledge of this extinct beaver genus.

The remains of Chalicomys so far known are represented mainly by isolated teeth (often only a few specimens) from several late Miocene to early Pliocene localities in Eurasia, i.e., Austria, Germany, Spain, Turkey, Ukraine, and Kazakhstan (see Kowalski 1967, Ünay 1974, Lychev 1977, Agadjanian and Erbajeva 1983, Hugueney 1999, Dema 2000, Korth 2002, Rekovets et al. 2009, Sen 2016).

A single maxillary fragment of Chalicomys jaegeri with nearly complete set of cheek teeth (lacking only the right M3) and mandibular fragments with p4-m2 were described from the type locality Eppelsheim (Kaup 1832, revised by
Stefen 2009). A maxilla and two mandibular fragments from Çanakkale, Turkey (Ünay 1974) as well as a single mandibular fragment with $\mathrm{p} 4-\mathrm{m} 2$ were reported from Küçükçekmece, Turkey (Sen 2016). Postcranial material assigned to this species has been described by DaxnerHöck (2004) from Mataschen, Austria (MN 7/8-9), and by Kowalski (1967) and Sen (2016) from other localities.

The isolated cheek teeth described herein and assigned to Chalicomys jaegeri are morphologically similar (if not identical) to those from other localities, in particular Eppelsheim and Küçükçekmece (Stefen 2009, Sen 2016). A main distinctive feature for Chalicomys are the hypostriid/ia on p4/P4 extending to the tooth base (Hugueney 1999, Stefen 2009, Mörs and Stefen 2010). All the teeth have a thin cement layer on striae/ids and resemble a basically tetralophodont pattern also characteristic for Chalicomys (Casanovas-Vilar and Alba 2011). Additional flexi/ids or fossettes/ids were not observed. One $\mathrm{p} 4$ shows an additional stylid at the base of a striid (Pl. 1, Fig. 2c), being also present
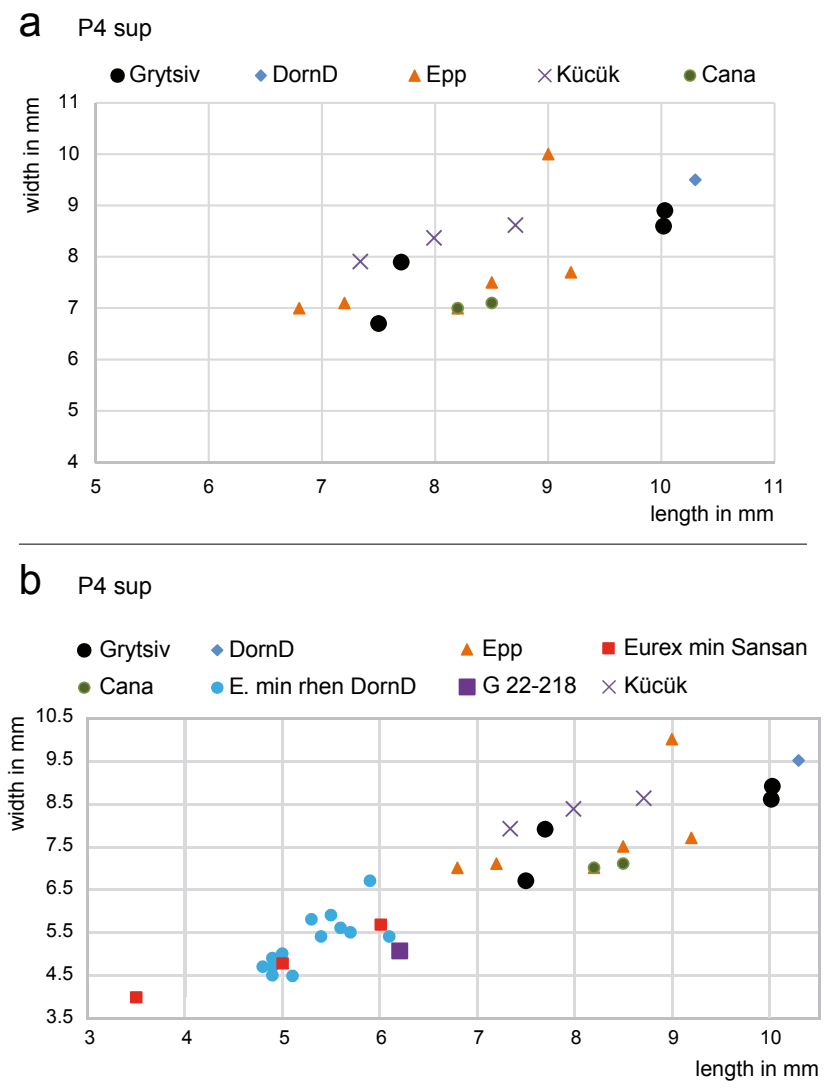

Text-fig. 2. Scatter diagram of the length/width ratio of the upper fourth premolar (P4) of Chalicomys jaegeri from Grytsiv as compared to those of $C$. jaegeri only (a) and additionally of Euroxenomys minutus rhenanus (E. min rhen), Euroxenomys minutus (Eurex min) (b) from other localities. Abbreviations for localities: Cana - Çanakkale (probably MN 8/9 after Sen 2016; data from Ünay 1974), DornD - Dorn-Dürkheim 1 (MN 11; data from Franzen and Storch (1975) for both C. jaegeri and E. minutus rhenanus), Epp - Eppelsheim (MN 9; Stefen 2009), Kücük - Küçükçekmece (probably MN 8/9; Sen 2016), and Sansan (MN 6 after Sen 1997; data from Hugueney and Duranthon 2012). A single specimen from Grytsiv (G) NMNHU-P 22/218 is tentatively assigned to Euroxenomys minutus based on its size. 
a
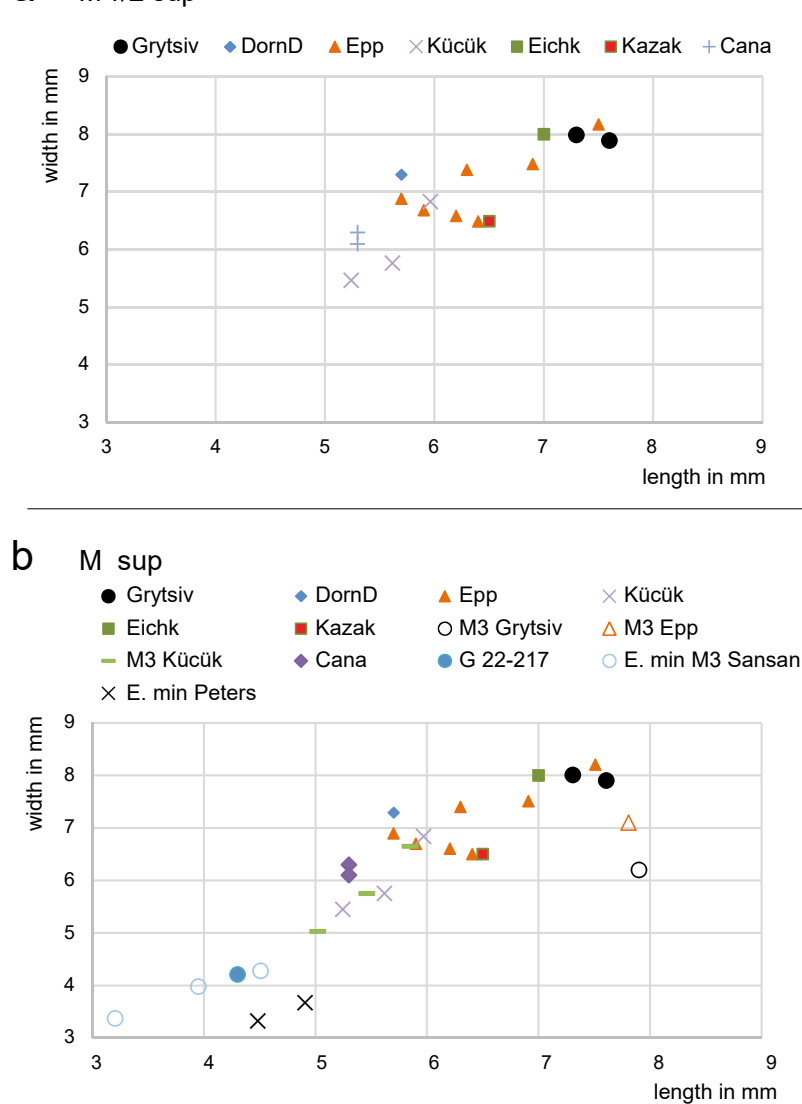

Text-fig. 3. Scatter diagram of the length/width ratio for upper molars (M1/2, if not indicated otherwise) of Chalicomys jaegeri from Grytsiv and comparable material from $C$. jaegeri only (a) and additionally of Euroxenomys minutus (E. min) (b) from Sansan and Petersbuch 50. Abbreviations as in Text-fig. 2. Eich - Eichkogel (data from Daxner-Höck 1980), Kazak Kazakhstan (data from Lychev 1977), Peters - Petersbuch 50 (MN 8; Stefen and Rummel 2003).

in other castorids, e.g., Steneofiber depereti from Gračanica (Stefen 2020). The teeth from Grytsiv are characterized by different wear stages: two specimens (M1/2 and M3) are strongly worn, three others (P4, p4, M3) are slightly worn (juvenile individuals), while all other specimens show medium to strong wear.

Nine teeth described herein are well comparable to those of Chalicomys jaegeri, and fall into the size range known for this species or slightly exceed it (Text-figs 2, 3). There are four upper premolars that at least partially indicate the variability of the species from Grytsiv, and the size range is particularly well comparable to that known from Eppelsheim. Measurements of premolars from five localities (MN 8/9-MN 11) indicate that the size range for $C$. jaegeri remains similar over these $\mathrm{MN}$ zones.

Meristic comparison supports the tentative assignment of two cheek teeth from Grytsiv to Euroxenomys minutus. They are comparable in size with P4 (Text-fig. 2b) and M3 (Text-fig. 3b) of this species; the size neither resembles C. jaegeri nor T. minutum from Dorn-Dürkheim 1 (Franzen and Storch 1975). The tooth falls into the size range of E. minutus from Sansan.

Chalicomys jaegeri, like other castorid species, is usually a single beaver species in the assemblage from each locality, e.g., Eppelsheim (other beaver species originally named by Kaup (1832) are all synonymised), Eichkogel (DaxnerHöck 1980), Çanakkale (Ünay 1974), or Küçükçekmece West (Sen 2016). Three beaver species were originally described from Dorn-Dürkheim 1, MN 11 (Franzen and Storch 1975). However, one of these species, Palaeomys plassi, was represented only by 2 teeth. One of them has been redetermined as Euroxenomys minutus rhenanus, and the other one - the holotype - assigned to $C$. jaegeri by Casanovas-Vilar and Alba (2011).

A few localities actually yielded the fossil remains of different beaver taxa. Among them, Hambach (MN 5) is characterized by the presence of Steneofiber depereti MAYET, 1908 (Mörs and Stefen 2010) and Anchitheriomys (Stefen and Mörs 2008), while the material from Sansan (MN 6) comprises Euroxenomys minutus and a handful number of specimens assigned to Steneofiber aff. eseri (Hugueney and Duranthon 2012). Thus, Grytsiv is one of such localities from which at least two beaver species of different size are known.

Extant beavers are generally associated with a semiaquatic lifestyle. The same is also assumed for some Miocene forms as revealed by the finding of a fossilized beaver lodge full of nicely preserved postcranial remains belonging to several individuals of Steneofiber castorinus (Hugueney and Escuillié 1995). Thus, beaver remains are expected to be associated with lacustrine, fluviatile, or swampy deposits. Only few beaver remains have so far been found in karstic environments and fissure fillings (e.g., a small species from Węże (MN 15; Sulimski 1964); Euroxenomys minutus from Petersbuch 50 (MN 8; Stefen and Rummel 2003)). Knowing the lifestyle of extant beavers with an affinity to water, it should be expected that they are rare or absent as well in generally drier karstic environments. Beavers might have been brought into such areas by birds of prey or carnivores, or lived in small nearby creeks.

\section{Acknowledgements}

We are thankful to editors of the volume for the invitation to participate. We are indebted to O. Kovalchuk (Kyiv) for his kind help during the preparation of the manuscript and critical reading of the text. D. Nowakowski (Wrocław) and M. Fischer (Dresden) are acknowledged for preparing the photographs and placing them on plate. We thank E. Orrison for proofreading as well as the reviewers I. CasanovasVilar (Barcelona) and J. Prieto (Munich) for their fruitful comments that significantly improved the manuscript.

\section{References}

Agadjanian, A. K., Erbajeva, M. A. (1983): Pozdnekaynozoyskie gryzuny i zaytseobraznye territorii SSSR [Late Cenozoic rodents and lagomorphs from the territory of the USSR]. - Nauka, Moscow, 188 pp. (in Russian)

Aldana Carrasco, E. J. (1992): Los Castoridae (Rodentia, Mammalia) del Neógeno de Cataluña (España) [Neogene Castoridae (Rodentia, Mammalia) from Cataluña (Spain)]. - Treballs del Museu de Geologia de Barcelona, 2: 99-141. (in Spanish) 
Apoltsev, D. A., Neofitny, S. V. (2014): Mistseznakhodzhennia reshtok vymerlykh bobriv (Castoridae, Rodentia) pizniogo miocenu Ukrainy [Localities with late Miocene remains of extinct beavers (Castoridae, Rodentia) in Ukraine]. - Pryrodnychyi almanakh, Seria Biologichni nauky, 20: 40-46. (in Ukrainian)

Apoltsev, D. A., Rekovets L. I. (2015): Beavers of the genus Trogontherium (Castoridae, Rodentia) from the late Miocene of Ukraine. - Vestnik Zoologii, 49(2): 451-456. https://doi.org/10.1515/vzoo-2015-0062

Casanovas-Vilar, I., Alba, D. M. (2011): The never-ending problem of Miocene beaver taxonomy. - Acta Palaeontologica Polonica, 56(1): 217-221. https://doi.org/10.4202/app.2010.0051

Casanovas-Vilar I., Alba, D. M., Almecija, S., Robles, J. M., Galindo, J., Moya-Sola, S. (2008): Taxonomy and paleobiology of the genus Chalicomys Kaup, 1832 (Rodentia, Castoridae), with the description of a new species from Abocador De Can Mata (Vallès-Penedès Basin, Catalonia, Spain). - Journal of Vertebrate Paleontology, 28: 851-862.

https://doi.org/10.1671/0272-4634(2008)28[851:TAPOTG]2.0.CO;2

Crusafont Pairó, M., Villalta, J. F. de, Bataller, J. R. (1948): Los castores fósiles de España [Fossil castorids from Spain]. - Boletín del Instituto Geológico y Minero de España, 61: 321-423. (in Spanish)

Daxner-Höck, G. (1980): Rodentia (Mammalia) des Eichkogels bei Mödling (Niederösterreich) 1. Spalacinae und Castoridae 2. Übersicht über die gesamte Nagetierfauna. - Annalen des Naturhistorischen Museums in Wien, 83: $135-152$. https://doi.org/10.1007/BF02986045

Daxner-Höck, G. (2004): Biber und ein Zwerghamster aus Mataschen (Unter-Pannonium, Steirisches Becken). Joannea - Geologie und Paläontologie, 5: 19-33.

Dema, L. (2000): The first finds of beavers of the genus Dipoides (Castoridae, Rodentia) in the Pliocene of Ukraine. - Vestnik Zoologii, 114(supplement): 117-119.

Franzen, J. L., Storch, G. (1975): Die unterpliozäne (turolische) Wirbeltierfauna von Dorn-Dürkheim, Rheinhessen (SW-Deutschland). - Senkenbergiana lethaea, 56(4-5): 233-303.

Hemprich, F. W. (1820): Grundriß der Naturgeschichte für höhere Lehranstalten. - Rücker, Berlin, $448 \mathrm{~s}$.

Horn, S., Durka, W., Wolf, R., Ermala, A., Stubbe, A., Stubbe, M., Hofreiter, M. (2011): Mitochondrial genomes reveal slow rates of molecular evolution and the timing of speciation in beavers (Castor), one of the largest rodent species. - PLoS ONE, 6(1): e14622 (9 pp.).

https://doi.org/10.1371/journal.pone.0014622

Horn, S., Prost, S., Stiller, M., Makowiecki, D., Kuznetsova, T., Benecke, N., Pucher, E., Hufthammer, A. K., Schouwenburg, C., Shapiro, B. Hofreiter, M. (2014): Ancient mitochondrial DNA and the genetic history of Eurasian beavers (Castor fiber) in Europe. - Molecular Ecology, 23: $1717-1729$.

https://doi.org/10.1111/mec.12691

Hugueney, M. (1999): Family Castoridae. - In: Rössner, G. E., Heissig, K. (eds), The Miocene Land Mammals of Europe. Verlag Dr. Friedrich Pfeil, München, pp. 281-300.
Hugueney, M., Duranthon, F. (2012): Les Castoridae (Rodentia) de Sansan. - In: Peigné, S., Sen, S. (eds), Mammifères de Sansan. Mémoires du Muséum national d'Histoire naturelle, Paris, 203: 95-118.

Hugueney, M., Escuillié, F. (1995): K-strategy and adaptive specialization in Steneofiber from Montaigu-le-Blin (dept. Allier, France; Lower Miocene, MN 2a $\pm 23 \mathrm{Ma}$ ): first evidence of fossil life-history strategies in castorid rodents. - Palaeogeography, Palaeoclimatology, Palaeoecology, 113: 217-225. https://doi.org/10.1016/0031-0182(95)00050-V

Kaup, J. (1832): Beschreibung dreyer Gattungen urweltlicher Nager des Zoologischen Museums zu Darmstadt welche von den jetzt lebenden Genera verschieden sind. - Isis, Leipzig, 1832(9): 992-996.

Korotkevich, E. L. (1988): Istoriya formirovaniya gipparionovoy fauny Vostochnoy Evropy [The history of the formation of hipparion fauna of Eastern Europe]. - Naukova Dumka, Kyiv, 164 pp. (in Russian)

Korth, W. W. (2002): Comments on the systematics and classification of the beavers (Rodentia, Castoridae). Journal of Mammalian Evolution, 8(4): 279-296. https://doi.org/10.1023/A:1014468732231

Kovalchuk, O. M. (2017): Regional fish-based biostratigraphy of the Late Neogene and Pleistocene of southeastern Europe. - Vestnik Zoologii, 51(5): 375-392. https://doi.org/10.1515/vzoo-2017-0045

Kowalski, K. (1967): Rodents from the Miocene of Opole. Acta zoologica cracoviensia, 12(1): 1-6.

Lychev, G. F. (1977): Iskopaemye bobry (Castoridae, Rodentia) Kazakhstana [Fossil beavers (Castoridae, Rodentia) of Kazakhstan]; Avtoreferat disertacii na soiskanie stepeni kandidata biologicheskikh nauk [Summary of $\mathrm{PhD}$ thesis in Biology]. - MS, Institute of Zoology of the Academy of Sciences of USSR, Kyiv, Ukraine, 23 pp. (in Russian) (copy in the library of Schmalhausen Institute of Zoology, National Academy of Sciences of Ukraine)

Maul, C. L, Heinrich, W.-D., Rekovets, L. (2013): Kurze Übersicht zum Kenntnisstand der fossilen Bibergattung Trogontherium (Castoridae, Rodentia). - Säugetierkundliche Informationen, 9: 143-152.

Mayet, L. (1908): Étude des Mammifères miocènes des sables de l'Orléanais et des faluns de la Touraine. - Annales de l'Université de Lyon, Nouvelle Série I, 24: 1-316. https://doi.org/10.5962/bhl.title.52982

Meyer, H. von (1838): Mittheilungen an Professor Bronn gerichtet. - Neues Jahrbuch für Mineralogie, Geognosie, Geologie und Petrefaktenkunde, 1838: 413-418.

Mörs, T., Stefen, C. (2010): The castorid Steneofiber from NW Germany and its implications for the taxonomy of Miocene beavers. - Acta Palaeontologica Polonica, 55(2): 189-198. https://doi.org/10.4202/app.2009.0013

Nesin, V. A. (2013): Neogenovye Murinae (Rodentia, Muridae) Ukrainy [Neogene Murinae (Rodentia, Muridae) of Ukraine]. - Universitets'ka kniga, Sumy, 174 pp. (in Russian)

Nesin, V. A., Nadachowski, A. (2001): Late Miocene and Pliocene small mammal faunas (Insectivora, Lagomorpha, Rodentia) of Southeastern Europe. - Acta zoologica cracoviensia, 44(2): 107-135. 
Nowakowski, D., Rekovets, L., Kovalchuk, O., Pawlina, E., Demeshkant, V. (2018): Enamel ultrastructure of molars in $\uparrow$ Anomalomys gaillardi and some spalacid taxa (Rodentia, Mammalia). - Palaeontologia Electronica, 21.2.19A: 1-15. https://doi.org/10.26879/846

Rekovets, L., Kopij, G., Nowakowski, D. (2009): Taxonomic diversity and spatio-temporal distribution of late Cenozoic beavers (Castoridae, Rodentia) of Ukraine. Acta zoologica cracoviensia, 52(1-2): 95-105. https://doi.org/10.3409/azc.52a 1-2.95-105

Rekovets, L. I., Kovalchuk, O. M. (2017): Phenomenon in the evolution of voles (Mammalia, Rodentia, Arvicolidae). - Vestnik Zoologii, 51(2): 99-110. https://doi.org/10.1515/vzoo-2017-0015

Rekovets, L., Nowakowski, D. (2013): Zahlschmelz-Ultrastrukturen an Backenzähnen verschiedener Vertreter der Familie Castoridae (Rodentia, Mammalia) aus der Ukraine. - Säugetierkundliche Informationen, 9: 159163.

Rybczynski, N. (2007): Castorid Phylogenetics: Implications for the Evolution of Swimming and Tree-Exploitation in Beavers. - Journal of Mammalian Evolution, 14(1): 1-35. https://doi.org/10.1007/s10914-006-9017-3

Samson, P., Rădulesco, C. (1973): Remarques sur l'évolution des Castoridés (Rodentia, Mammalia). - In: Colloque national de Spéléologie, Livre du cinquantenaire de l'Institut de Spéléologie "Émile Racovitza". Ed. Academiei Republicii Socialiste România, Bucureşti, pp. 437-449.

Sen, S. (1997): Magnetostratigraphic calibration of the European Neogene mammal chronology. - Palaeogeography, Palaeoclimatology, Palaeoecology, 133(3-4): 181-204. https://doi.org/10.1016/S0031-0182(97)00079-5

Sen, S. (2016): Rodents, lagomorphs and insectivores. Geodiversitas, 38(2): 299-314. https://doi.org/10.5252/g2016n2a9

Stefen, C. (2009): The European Tertiary beaver Chalicomys jaegeri (Rodentia: Castoridae) revisited. - Kaupia, 16: 161-175.

Stefen, C. (2011): A Brief Overview of the Evolution of European Tertiary Beavers. - Baltic Forestry, 17(1): 148-153.

Stefen, C. (2020): The castorids (Mammalia, Castoridae) from the (early) middle Miocene of Gračanica (Bos-
nia-Herzegovina). - Palaeobiodiversity and Palaeoenvironments, 100(2): 301-305.

https://doi.org/10.1007/s12549-018-0365-9

Stefen, C., Mörs, T. (2008): The beaver Anchitheriomys from the Miocene of Central Europe. - Journal of Paleontology, 82(5): 1009-1020. https://doi.org/10.1666/06-049.1

Stefen, C., Rummel, M. (2003): Trogontherium (Euroxenomys) minutum (Castoridae: Mammalia) from Petersbuch 50, Miocene, South Germany. - Neues Jahrbuch für Geologie und Paläontologie, Monatshefte, 2003(1): 11-34. https://doi.org/10.1127/njgpm/2003/2003/11

Stirton, R. A. (1935): A review of the Tertiary beavers. University of California publications, Bulletin of the Department of geological sciences, 23(13): 391-458.

Sulimski, A. (1964): Pliocene Lagomorpha and Rodentia from Węże I (Poland). - Acta Palaeontologica Polonica, 9(2): 149-264.

Topachevsky, V. A., Nesin V. A., Topachevsky I. V. (1997): Ocherk istorii mikroteriofaun (Insectivora, Lagomorpha, Rodentia) Ukrainy v otrezke vremeni sredniy sarmatakchagyl [An essay of the small mammal fauna history (Insectivora, Lagomorpha, Rodentia) in Ukraine during middle Sarmat-Aktshagyl Period]. - Vestnik Zoologii, 31(5-6): 3-14. (in Russian)

Topachevsky, V. A., Nesin, V. A., Topachevsky, I. V., Semenov, Yu. A. (1996): Dreveyshee mestonakhozhdenie srednesarmatskoy mikroteriofauny (Insectivora, Lagomorpha, Rodentia) v Vostochnoy Evrope [The oldest locality of the Sarmatian microtheriofauna (Insectivora, Lagomorpha, Rodentia) in Eastern Europe]. - Dopovidi NAN Ukrainy, 2: 107-110. (in Russian)

Topachevsky, V. A., Scorik, A. F., Rekovets L. I. (1987): Gryzuny verkhneneogenovykh i ranneantropogenovykh otlozheniy Khadzhibeyskogo limana [Rodents of Upper Neogene and Early Anthropogene deposits of Khadzhibey Estuary]. - Naukova Dumka, Kyiv, 208 pp. (in Russian)

Ünay, E. (1974): The remains of Steneofiber jaegeri Kaup (Rodentia, Mammalia) found in the Çanakkale region. - Bulletin of the Mineral Resources Exploration, 86: 95-100.

Wood, A. E., Wilson, R. W. (1936): A suggested nomenclature for the cusps of the cheek teeth of rodents. - Journal of Paleontology, 10(5): 388-391 


\section{Explanations to the plate}

\section{PLATE 1}

Chalicomys jaegeri, late Miocene, Grytsiv

1. Right p4, NMNHU-P 22/214, in occlusal (a), buccal (b) and lingual (c) view.

2. Right p4, NMNHU-P 22/215, in occlusal (a), buccal (b) and lingual (c) view.

3. Left M1 or M2, NMNHU-P 22/220, in occlusal view.

4. Left M1 or M2, NMNHU-P 22/219, in occlusal view.

5. Right P4 (strongly worn), NMNHU-P 22/212, in occlusal (a) and lingual (b) view.

6. Right P4, NMNU-P 22/213, in oblique occlusal (a) and lingual (b) view.

7. Left P4, NMNHU-P 22/211, in occlusal (a) and buccal (b) view.

8. Left P4, NMNHU-P 22/216, in occlusal view with a strongly curved mesoflexus (a) and lingual view (b).

9. Probably right M3 (strongly worn), NMNHU-P $22 / 222$, in occlusal view.

cf. Euroxenomys minutus, late Miocene, Grytsiv

10. Left M3, NMNHU-P 22/217, in occlusal (a) and buccal (b) view.

11. Right P4, NMNHU-P 22/218, in occlusal (a) and lingual (b) view.

Scale bar equals $1 \mathrm{~mm}$ for all figured teeth. 
PLATE 1

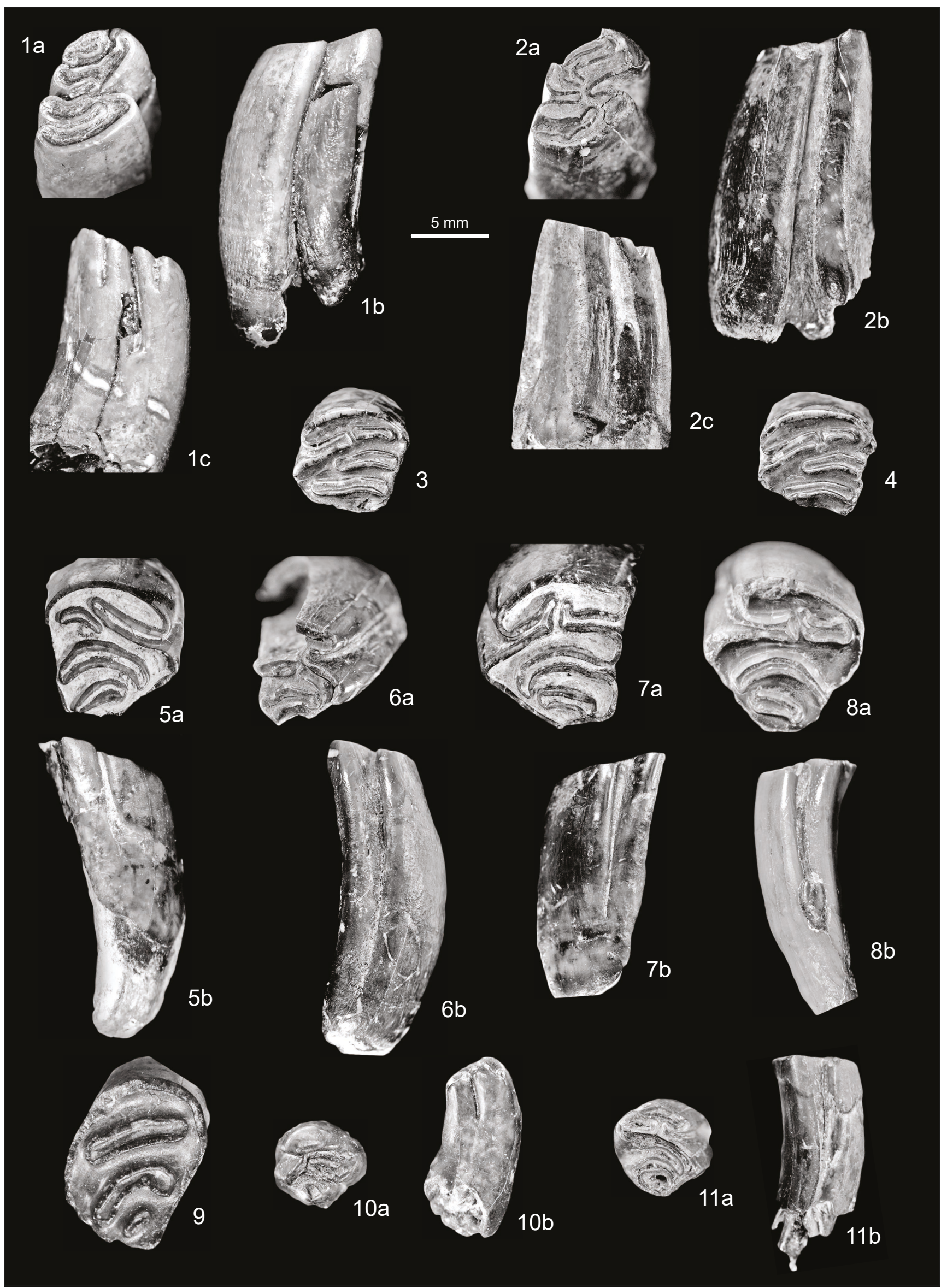

